\title{
ANALISIS BREAK EVENT POINT (BEP) PADA PABRIK TEH PT. PERKEBUNAN NUSANTARA VI UNIT USAHA KAYU ARO
}

\section{BREAK EVENT POINT (BEP) ANALYSIS ON TEA FACTORY PT. PERKEBUNAN NUSANTARA VI KAYU ARO BUSINESS UNIT}

\author{
Emanauli, Fenny Permata Sari and Fera Oktaria
}

\begin{abstract}
Program Studi Teknologi Industri Pertanian, Fakultas Pertanian, Universitas Jambi, Jl. Tribrata KM. 11, Pondok Meja, Mestong, Muaro Jambi, Jambi 36364, Indonesia emanauli@yahoo.com, fenny.permatasari01@gmail.com, fee.okt@gmail.com
\end{abstract}

\begin{abstract}
ABSTRAK
Penelitian ini bertujuan untuk mengetahui gambaran proses produksi perusahaan, permasalahan yang dihadapi dan menentukan nilai titik impas/Break Event Point (BEP). Penelitian menggunakan metode studi kasus. Analisa data yang digunakan adalah analisa kuantitatif dan analisa deskriptif. Hasil penelitian menunjukkan aktivitas proses produksi dilakukan secara terus menerus (continue process). Permasalahan yang terjadiyaitu umurpabrik yang cukup lama sehingga sering mengalami kerusakan dan penurunan pasokan bahan baku. Perhitungan BEP dilakukan dengan pendekatan matematis dan pendekatan grafis. Hasil penelitian menunjukkan nilai BEP pada pabrik teh PT. Perkebunan Nusantara VI Unit Usaha Kayu Aro tahun 2019 adalah pada tingkat penjualan sebesar $4.562 .047 \mathrm{~kg}$ atau pada tingkat penjualan sebesar Rp. 79.379.611.052.
\end{abstract}

Kata kunci : teh;Break Event Point (BEP); biaya

\section{ABSTRACT}

This study aims to describe the company's production process, the problems faced and determine the value of the break-even point (BEP).This research uses the case study method.The data analysis used is quantitative analysis and descriptive analysis.The results showed that the activities of the production process were carried out continuously (continue process).The problem that occurs is that the factory is long enough to experience damage and a decrease in the supply of raw materials.The calculation of BEP is carried out using a mathematical approach and a graphical approach.The results showed the value of BEP at the tea factory PT.Perkebunan Nusantara VI Kayu AroBusiness Unit in 2019 is at a sales level of 4,562,047 $\mathrm{kg}$ or at a sales levelof Rp.79,379,611,052.

Keywords: tea: Break Event Point (BEP); cost

\section{Pendahuluan}

Industri teh termasuk salah satu contoh agroindustri yang banyak bermunculan saat ini. Agroindustri teh mempunyai peranan yang penting dalam perekonomian Indonesia karena teh merupakan salah satu kebutuhan pokok masyarakat yang tingkat konsumsinya tinggi.Bahan baku yang digunakan pada industri teh berasal dari tanaman teh. Tanaman teh cocok ditanam di daerah

pegunungan karena merupakan tanaman tahunan yang berasal dari daerah subtropis (hindersah dkk, 2016).Bagian dari tanaman teh yang digunakan adalah daun teh. Untuk menghasilkan daun teh yang siap dikonsumsi maka daun teh tersebut akan diolah / diproses terlebih dahulu.

Provinsi Jambi sektor perkebunan memegang peranan yang penting dalam pendapatan daerah. Salah satu komoditi 
unggulan perkebunan Jambi adalah teh. Menurut data Badan Pusat Statistik tahun 2018, luas tanaman teh di Provinsi Jambi mengalami peningkatan beberapa tahun terakhir yaitu pada tahun 2015 seluas 2.324 ha, tahun 2016 seluas 2.326 ha dan tahun 2017 seluas 2.331 ha. Begitu juga dengan jumlah produksi juga mengalami peningkatan yaitu 3.555 ton pada tahun 2015, 5.268 ton tahun 2016 dan 5.272 ton tahun 2017 (BPS Provinsi Jambi, 2019).

Dari sisi ekspor, volume ekspor teh Indonesia data tahun 2017adalah 54.195 ton dengan nilai US\$ 114.232 juta. Sedangkan impor teh oleh Indonesia adalah sebesar 14.679 ton dengan nilai US\$ 26.224 juta (BPS, 2017).Produsen teh lebih cendrung untuk mengekspor teh karena harga di pasar Internasional lebih tinggi, hal ini disebabkan karena banyaknya permintaan teh dari luar negeri.

Break Event Point (BEP) merupakan suatu kondisi dimana perusahaan tidak memperoleh laba dan juga tidak menderita kerugian. Artinya antara biaya dan pendapatan berada pada kondisi yang sama (labanya sama dengan 0) (Purwanti dan Darsono, 2013) Analisis Break Event Point (BEP) adalah teknik analisis untuk mempelajari hubungan antara volume penjualan dan profitabilitas. Analisis BEP bertujuan untuk mengetahui tingkah laku biaya dan keuntungan dimana biaya menentukan harga jual, harga jual mempengaruhi volume penjualan, volume penjualan volume produksi mempengaruhi biaya. (Gestia dan Hamidi, 2017).Analisa ini disebut juga dengan analisa impas, yaitu suatu metode yang digunakan untuk menentukan titik tertentu, dimana penjualan dapat menutup biaya, sekaligus menunjukkan besarnya keuntungan atau kerugian perusahaan jika penjualan melampaui atau berada dibawah titik.

PT. Perkebunan Nusantara VI merupakan satu-satunya perusahaan BUMN di Provinsi Jambi yang memproduksi teh. Teh yang dihasilkan adalah teh hitam melalui 2 jenis proses pengolahan yaitu pengolahan secara CTC dan pengolahan secara Ortodox. Berdasarkan data total produksi teh tahun 2016-2018 mengalami peningkatan sebesar $3,08 \%$ total produksi tahun 2016 jika dibandingkan tahun 2017 meningkat sebesar 40,97\% dan tahun 2017 jika dibandingkan tahun 2018 juga mengalami kenaikan sebesar $44,05 \%$. Akan tetapi data total produksi teh tahun 2018 jika dibandingkan tahun 2019 mengalami penurunan sebesar $0,82 \%$.

Tertarik akan hal diatas maka penulis tertarik untuk melakukan penelitian yang berjudul "Analisis Break Event Point (BEP) Pada Pabrik Teh PT. Perkebunan Nusantara VI Unit Usaha Kayu Aro".Berdasarkan permasalahan yang telah diuraikan diatas, maka penelitian ini bertujuan untuk :

1. Mengetahui gambaran proses produksi perusahaan dan permasalahan yang dihadapi tahun 2020

2. Menentukan nilai titik impas / break event point

\section{Metode Penelitian}

Penelitian ini dilaksanakan di Pabrik teh PT. Perkebunan Nusantara VI Unit Usaha Kayu Aro. Metode yang digunakan dalam penelitian ini adalah metode studi kasus. Data yang dikumpulkan adalah data primer dan data sekunder. Metode yang digunakan untuk pengambilan responden adalah metode purposive sampling.

Variabel-variabel pada penelitianini adalah penggunaan bahan baku, proses produksi, jenis mesin, peralatan dan teknologi yang digunakan, tenaga kerja, pendapatan, biaya, volume produksi, harga jual per satuan, tingkat penjualan. Untuk mengetahui gambaran umum proses produksi dan masalah-masalah yang terjadi dalam proses produksi perusahaan dianalisis secara deskriptif. Perhitungan Break Event Point (BEP) dilakukan dengan menggunakan dua pendekatan yaitu pendekatan matematis dan pendekatan grafis.

Break Event Point adalah titik kegiatan (volume penjualan) dimana total 
pendapatan (revenue) sama dengan total biaya (Rudzali dan Damayanti,2015). Adapun kegunaan dari Break Event Point adalah untuk membantu manajemen dalam penyusunan anggaran, untuk mengetahui kemampuan perusahaan dalam menekan biaya dan batas dimana perusahaan tidak mengalami laba dan rugi, untuk mengetahui struktur biaya tetap dan biaya variabel (Siswanto dkk, 2018). Perhitungan titik impas dapat dilakukan dengan 2 cara yaitu :

a. Pendekatan Matematis

1. Titik Impas (Unit/Tahun)

$$
=\frac{T F C}{P-V C \text { per unit }}
$$

2. Titik Impas (Rp/Tahun)

$$
=\frac{T F C}{1-\frac{\text { VC per unit }}{P}}
$$

Dimana :

$$
\begin{aligned}
& \mathrm{P} \quad=\text { Harga jual per unit } \\
& \text { TFC = Biaya Tetap } \\
& \text { VC per unit }=\text { Biaya variabel per } \\
& \text { Unit }
\end{aligned}
$$

Pada keadaaan titik impas laba operasinya sama dengan nol,

\section{Pendapatan}

sehinggaakan menghasilkan jumlah produk (dalam satuan unit maupun satuan uang penjualan) yang dijual mencapai titik impas ditambah biaya tetap(Maruta, 2018).

b. Pendekatan Grafis

Break Event Point dapat dihitung dengan grafik atau gambar. Dengan grafik break event point kita dapat mengetahui hubungan antara biaya, penjualan (volume penjualan) dan laba. Selain itu juga dapat mengetahui besarnya biaya yang tergolong biaya tetap dan biaya variabel serta dapat mengetahui tingkat-tingkat penjualan yang masih menimbulkan kerugian dan tingkat penjualan yang sudah menimbulkan laba/besarnya laba/rugi pada satu tingkat penjualan tertentu (Munawir, 2004).

Menurut Choiriyah dkk (2016), break event point akan diperoleh jika terjadi pertemuan antara garis penghasilan dengan garis biaya didalam satu grafik, dapat dilihat pada Gambar 1 dibawah ini.

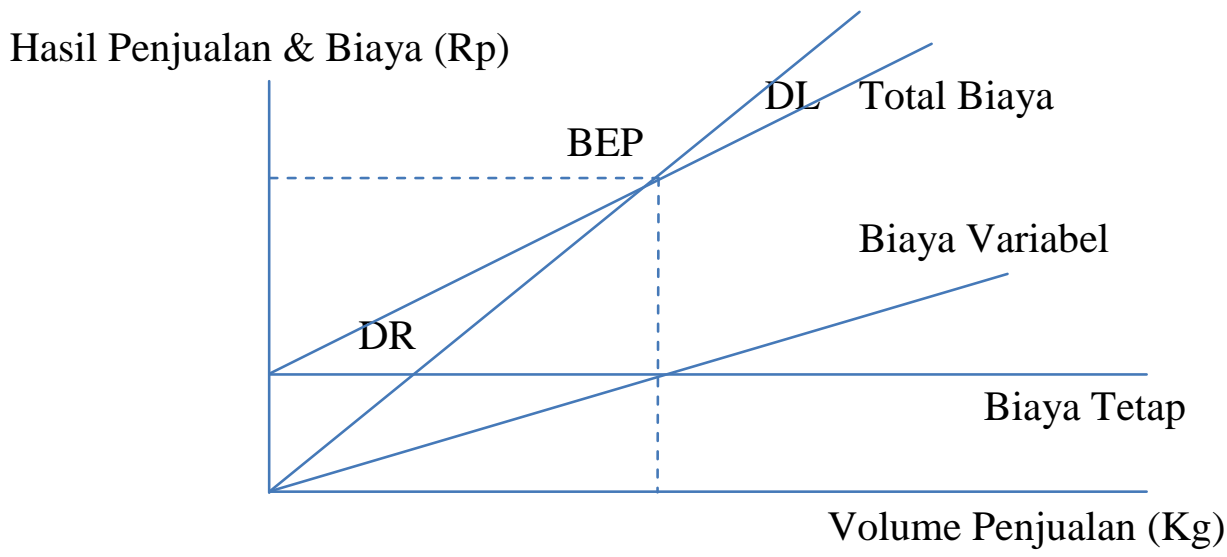

Gambar 1. Grafik Break Event Point

Daerah diatas (disebelah kanan) nilai titik break event point adalah daerah dimana perusahaan memperoleh laba karena penerimaan lebih besar dari pada biaya yang harus dikeluarkan perusahaan. Sedangkan daerah dibawah (disebelah kiri) titik
Break Event Point adalah daerah dimana perusahaan mengalami kerugian karena penerimaan yang diterima perusahaan tidak dapat menutupi biaya total yang dikeluarkan perusahaan (Rudzali dan Damayanti, 2015). Semakin besar nilai Break 
Event Point maka semakin kecil kemungkinan memperoleh kesempatan untuk memperoleh laba.

\section{Hasil Dan Pembahasan Gambaran Umum Perusahaan}

Pada tahun 1920 perusahaan Belanda NVHVA (Namlodse Venotchaaf Handle Veriniging Amsterdam) membuka Unit Usaha Kayu Aro di PT. Perkebunan Nusantara VI. Pada awalnya etnis Jawa dipekerjakan sebagai penanam dan pengurus pabrik teh yang ada di Kecamatan Kayu Aro (Sumarno dan Fikriman, 2019). Teh hitam (Ortodox) adalah teh yang dihasilkan sejak mulai operasi. Penanaman pertama dilakukan tahun 1923 dan pendirian pabrik teh dilakukan tahun 1925 . Unit Usaha Kayu Aro telah menjadi salah satu unit kebun dari PT. Perkebunan Nusantara VI sejak mulai 11 Maret 1996. Unit Usaha Kayu Aro terletak di Desa Bedeng VIII Kecamatan Kayu Aro Kabupaten Kerinci Provinsi Jambi. Letak PT. Perkebunan Nusantara VI Unit Usaha Kayu Aro berdasarkan pusat kota dan pelabuhan terdekat dapat dilihat pada Tabel 1. Letak PT. Perkebunan Nusantara VI Unit Usaha Kayu Aro berdasarkan geografis dapat dilihat pada Tabel 2.PT. Perkebunan Nusantara VI Unit Usaha Kayu Aro, berdasarkan kondisi cuaca / iklim dapat dilihat pada Tabel 3 .

Tabel 1. Letak Perusahaan Dari Pusat Kota / Pelabuhan Terdekat

\begin{tabular}{llc}
\hline No & \multicolumn{1}{c}{ Lokasi } & Jarak (km) \\
\hline 1 & Ibukota Kabupaten (Sungai Penuh) & 37 \\
2 & Ibukota Provinsi (Jambi) & 452 \\
3 & Pelabuhan Teluk Bayur Padang Via Pesisir Selatan & 325 \\
4 & Pelabuhan Teluk Bayur Padang Via Muara Labuh & 237 \\
\hline
\end{tabular}

Sumber : PT. Perkebunan Nusantara VI Unit Usaha Kayu Aro, 2019.

Tabel 2. Letak Geografis PT. Perkebunan Nusantara VI Unit Usaha Kayu Aro

\begin{tabular}{lll}
\hline No & \multicolumn{1}{c}{ Posisi dan Elevasi } & \multicolumn{1}{c}{ Keterangan } \\
\hline 1 & Letak kebun & $1^{\circ} 46,978^{\circ} \mathrm{LS} \mathrm{s} / \mathrm{d} 101^{\circ} 16,856^{\circ} \mathrm{BT}$ \\
2 & Letak pabrik & $1^{\circ} 49^{\prime} 22^{\prime} \mathrm{S} \mathrm{s} / \mathrm{d} 1^{\circ} 1015^{\prime} 28^{\prime \prime} \mathrm{E}$ \\
3 & Elevasi pabrik & $1.430 \mathrm{mdpl}$ \\
4 & Elevasi kebun terendah & $1.401 \mathrm{mdpl}$ \\
5 & Elevasi kebun tertinggi & $1.715 \mathrm{mdpl}$ \\
\hline
\end{tabular}

Sumber : PT. Perkebunan Nusantara VI Unit Usaha Kayu Aro, 2019.

Tabel 3. Kondisi Cuaca / iklim PT. Perkebunan Nusantara VI Unit Usaha Kayu Aro

\begin{tabular}{|c|c|c|}
\hline No & Cuaca / Iklim & Keterangan \\
\hline 1 & Curah hujan rata-rata / tahun & $2.000 \mathrm{~mm}$ \\
\hline 2 & Hari hujan rata-rata / tahun & 200 hari \\
\hline 3 & Sinar matahari rata-rata / tahun & 6 jam / hari \\
\hline 4 & Suhu udara & $17-23^{\circ} \mathrm{C}$ \\
\hline 5 & Suhu minimum & $5^{\circ} \mathrm{C}$ \\
\hline 6 & Kelembaban nisbi (Rh) & $70-95 \%$ \\
\hline
\end{tabular}

Sumber : PT. Perkebunan Nusantara VI Unit Usaha Kayu Aro, 2019.

\section{Faktor Sumber Daya dan Karyawan Perusahaan}

Klasifikasinya tenaga kerja Pabrik

Teh dapat dilihat pada Tabel 4 
Tabel 4. Klasifikasi Tenaga Kerja Pabrik Teh PT. Perkebunan Nusantara VI Unit Usaha Kayu Aro Tahun 2019

\begin{tabular}{llc}
\hline No & \multicolumn{1}{|c}{$\begin{array}{c}\text { Klasifikasi } \\
\text { Jabatan }\end{array}$} & $\begin{array}{c}\text { Jumlah } \\
\text { (Orang) }\end{array}$ \\
\hline $\mathbf{1}$ & $\begin{array}{l}\text { Karyawan } \\
\text { pimpinan }\end{array}$ & 7 \\
$\mathbf{2}$ & $\begin{array}{l}\text { Karyawan } \\
\text { pelaksana }\end{array}$ & 125 \\
$\mathbf{3}$ & $\begin{array}{l}\text { PKWT / honor } \\
\text { Total }\end{array}$ & 103 \\
& $\mathbf{2 3 5}$ \\
\hline
\end{tabular}

Sumber:PT. Perkebunan NusantaraVI Unit Usaha Kayu Aro, 2019.

Pada Tabel 4 terlihat bahwa Jumlah tenaga kerja di Pabrik Teh PT. Perkebunan Nusantara VI Unit Usaha Kayu Aro adalah 235 orang. Jumlah karyawan pimpinan sebanyak 7 orang, karyawan pelaksana 125 orang dan jumlah PKWT / honor adalah 103 orang. Klasifikasi tenaga kerja pabrik teh PT. Perkebunan Nusantara VI Unit Usaha Kayu Aro seacara rinci dapat dijelaskan sebagai berikut :

a. Karyawan pimpinan

Merupakan tenaga kerja yang telah mendapatkan Surat Keputusan (SK) dari perusahaan. Karyawan pimpinan diangkat dan diberhentikan oleh direksi. Karyawan pimpinan adalah karyawan dengan golongan III dan IV. Yang tergolong karyawan pimpinan adalah Manajer, Kepala Pabrik, Kepala Tata Usaha Keuangan, Asisten Teknik dan Asisten Pengolahan.

b. Karyawan pelaksana

Merupakan tenaga kerja yang telah mendapatkan Surat Keputusan (SK) dari perusahaan. Karyawan pelaksana diangkat dan diberhentikan oleh direksi. Karyawan pelaksana adalah karyawan dengan golongan I dan II. Yang tergolong karyawan pelaksana adalah mandor I, Mandor, Karani Pengolahan, Krani Upah dan karyawan-karyawan proses produksi.

c. PKWT/honor

PKWT adalah karyawan dengan status kontrak dengan perusahaan. Karyawan dengan status kontrak berarti akan bekerja sepanjang kontrak yang telah disepakati.

\section{Faktor Manajemen Produksi dan Operasi}

PT. Perkebunan Nusantara VI Unit Usaha Kayu Aro memproduksi teh hitam dengan pengolahan secara CTC dan Ortodox. Pengolahan teh hitam Ortodox yaitu teh yang diolah melalui proses pelayuan sekitar 16 jam, penggulungan, fermentasi, pengeringan, sortasi, hingga terbentuk teh jadi. Teh CTC yakni teh yang diolah melalui perajangan, penyobekan, dan penggulungan daun basah menjadi bubuk kemudian dilanjutkan dengan fermentasi, pengeringan, sortasi, hingga terbentuk teh jadi (Rosyadi, 2001; Thanoza dkk, 2016).

Pengolahan teh hitam secara CTC dan Ortodox di PT. Perkebunan Nusantara VI Unit Usaha Kayu Aro dimulai dari penimbangan pucuk, analisa mutu pucuk, penyebaran di palung pelayuan WT (Whithering Through), pelayuan, pembalikan dan kirap.Tahapan lanjutan kegiatan pengolahan teh hitam orthodox adalah penurunan pucuk layu, penggilingan dan penggulungan, oksidasi enzimatis (fermentasi), pengeringan, dan sortasi kering, Tahapan lanjutan kegiatan pengolahan teh hitam CTC adalah turun daun layu, ayakan pucuk di GLS, penggilingan dan penggulungan, googie, oksidasi enzimatis (fermentasi), pengeringan, dan sortasi kering. Tahap akhir dari kegiatan pengolahan teh hitam CTC dan Ortodox adalah analisa mutu (Uji Densitas, Uji Organoleptik dan Uji Kadar Air) dan pengemasan. Adapun jumlah daun teh yang digunakan dan jumlah teh jadi yang dihasilkan setiap bulannya pada tahun 2019 dapat dilihat pada Tabel 5.

Dari Tabel 5 terlihat bahwa kenaikan jumlah bahan baku yang diolah juga diikuti dengan kenaikan jumlah produksi. Jumlah daun teh diolah terhitung dari bulan maret hingga bulan november rata-rata mengalami penurunan yaitu dari 1.844.397 $\mathrm{kg}$ menjadi $966.942 \mathrm{~kg}$, atau terjadi 
penurunan sebesar $48 \%$, namun meningkat kembali pada bulan desember sebesar $1.231 .218 \mathrm{~kg}$ atau meningkat sebesar $27 \%$.

Sedangkan Penggunaan jam kerja dari tenaga kerja belum mencapai kapasitas terpasang, sebagaimana terlihat pada Tabel 6

Tabel 5. Jumlah Daun Teh Yang Digunakan Dan Jumlah Teh Jadi Yang Dihasilkan PT. Perkebunan Nusantara VI Unit Usaha Kayu Aro Tahun 2019

\begin{tabular}{lrr}
\hline \multicolumn{1}{c}{ Bulan } & $\begin{array}{c}\text { Jumlah Daun Teh Diolah } \\
(\mathbf{K g})\end{array}$ & $\begin{array}{c}\text { Teh Jadi yang Dihasilkan } \\
(\mathbf{K g})\end{array}$ \\
\hline Januari & 1.696 .149 & 347.053 \\
Februari & 1.444 .851 & 304.977 \\
Maret & 1.844 .397 & 394.796 \\
April & 1.576 .737 & 330.109 \\
Mei & 1.575 .612 & 327.245 \\
Juni & 1.200 .456 & 252.117 \\
Juli & 1.487 .394 & 311.648 \\
Agustus & 1.004 .517 & 214.390 \\
September & 842.742 & 179.843 \\
Oktober & 834.408 & 175.745 \\
November & 966.942 & 200.871 \\
Desember & 1.231 .218 & 246.844 \\
Jumlah & 15.705 .423 & 3.285 .636 \\
\hline Sumber $:$ PT. Perkebur
\end{tabular}

Sumber : PT. Perkebunan Nusantara VI Unit Usaha Kayu Aro, 2019.

Tabel 6. Jam Kerja Tenaga Kerja Tahun 2017-2019

\begin{tabular}{ccc}
\hline Tahun & Jam Kerja Tenaga Kerja (Jam) & \% \\
\hline Kapasitas Terpasang & 493.500 & 100 \\
2017 & 356.157 & 72,17 \\
2018 & 390.936 & 79,22 \\
2019 & 390.936 & 79,22 \\
\hline
\end{tabular}

Sumber : PT. Perkebunan Nusantara VI Unit Usaha Kayu Aro, 2019.

Dari Tabel 6 dapat diketahui jumlah jam kerja tenaga kerja selama 3 tahun terakhir dan jumlah jam kerja tenaga kerja seharusnya jika bahan baku yang digunakan belum mencapai pada kapasitas terpasang. Dapat terlihat bahwa penggunaan jam kerja tenaga kerja tahun 2017-2019 masih dibawah kapasitas terpasang, yaitu tahun 2017 baru mencapai 356.157 jam $(72,17 \%)$ dan tahun 2018 dan 2019 baru mencapai 390.935 jam $(79,22 \%)$ dari kapasitas terpasang.

\section{Kendala Dalam Proses Produksi} Adanya kendala dalam proses produksi akan menghambat kelancaran proses produksi tersebut. Kendala yang dihadapi pabrik teh PT. Perkebunan Nusantara VI Unit Usaha Kayu Aro dalam proses produksi adalah umur pabrik yang cukup lama yang menyebabkan sering mengalami kerusakan yang memerlukan perbaikan yang relatif lama sehingga pabrik mengalami stagnasi pada bulan maret 2019. Terjadi penurunan pasokan bahan baku yang disebabkan karena adanya keterlambatan pemupukan daun pada bulan maret 2019, tidak terdapatnya pupuk urea pada bulan mei dan juli 2019; kurangnya curah hujan dan hari hujan pada bulan juli 2019, dengan curah hujan $39 \mathrm{~mm}$ dan tidak 
adanya hujan sama sekali pada bulan agustus 2019.

\section{Perhitungan Titik Impas}

Analisa titik impas digunakan untuk mengetahui batas bawah pendapatan yang tidak memberikan keuntungan dan kerugian bagi perusahaan. Adapun hal-hal yang berhubungan dengan analisis BEP yaitu suatu hubungan antara biaya tetap, biaya variabel, keuntungan, dan volume penjualan(Supriadi dkk, 2018).Variabel- variabel yang harus diketahui adalah pendapatan penjualan teh, biaya tetap dan biaya variabel.

\section{a. Pendapatan}

Besarnya pendapatan usaha dapat dihitung dengan mengalikan jumlah barang yang terjual dengan harga jual. Jumlah teh yang terjual dan pendapatan yang diperoleh PT. Perkebunan Nusantara VI Unit Usaha Kayu Aro setiap bulannya tahun 2019 dapat dilihat pada Tabel 7 .

Tabel 7. Volume Penjualan dan Pendapatan Penjualan Teh PT. Perkebunan Nusantara VI Unit Usaha Kayu Aro Tahun 2019.

\begin{tabular}{|c|c|c|}
\hline Bulan & Volume Penjualan (Kg) & $\begin{array}{l}\text { Pendapatan } \\
(\mathbf{R p})\end{array}$ \\
\hline Januari & 227.772 & 4.465 .823 .711 \\
\hline Februari & 226.872 & 4.353 .611 .575 \\
\hline Maret & 294.048 & 5.494 .319 .582 \\
\hline April & 362.034 & 6.619 .413 .797 \\
\hline Mei & 385.938 & 7.323 .494 .793 \\
\hline Juni & 324.954 & 6.204 .347 .951 \\
\hline Juli & 434.952 & 7.209.381.911 \\
\hline Agustus & 441.432 & 6.455 .961 .322 \\
\hline September & 377.226 & 6.214 .351 .946 \\
\hline Oktober & 421.920 & 7.324.581.483 \\
\hline November & 518.962 & 8.789 .497 .780 \\
\hline Desember & 669.461 & 11.074.767.202 \\
\hline Total & 4.685 .570 & 81.529 .553 .052 \\
\hline
\end{tabular}

Sumber : PT. Perkebunan Nusantara VI Unit Usaha Kayu Aro, 2019.

Dari Tabel 7 terlihat bahwa pendapatan dari penjualan teh selama tahun 2019 sebesar Rp. 81.529.553.052 dari volume penjualan sebesar $4.685 .570 \mathrm{~kg}$. Harga rata-rata teh sebesar Rp.17.400/kg. Berdasarkan total pendapatan produk maka didapatkan rata-rata pendapatan setiap bulan Rp. 6.794.129.421. Pendapatan tertinggi diperoleh pada bulan desember sebesar Rp. 11.074.767.202 dan pendapatan terendah pada bulan februari sebesar Rp. 4.353.611.575.

Dalam proses penjualan pemasaran produk, Unit Usaha Kayu Aro tidak mempunyai wewenang untuk bernegosiasi dengan pembeli, proses penjualan hanya dilakukan oleh bagian pemasaran yang berkedudukan di kantor pusat. Bubuk teh akan dijemput oleh pihak kantor pusat lalu dikemas dan dipasarkan. Daerah pemasaran tidak hanya di Provinsi Jambi tetapi juga disekitar Provinsi Jambi. Karena ciri khas rasa dan aromanya, teh kayu aro juga di ekspor sampai ke Benua Eropa.

\section{b. BiayaTetap}

Biaya tetap merupakan biaya yang jumlah totalnya tetap meskipun volume kegiatan bervariasi. Biaya-biaya yang tergolong sebagai biaya tetap pada perusahaan tahun 2019 adalah gaji karyawan pimpinan, gaji karyawan pelaksana, penyusutan, biaya asuransi, pajak, biaya keamanan, biaya listrik, biaya persediaan air, biaya komputer, biaya alat tulis dan beban bank. Dikarenakan 
penyusutan merupakan salah satu unsur biaya tetap maka terlebih dahulu dihitung nilai penyusutannya. Untuk nilai penyusutan pada bangunan, mesin dan instalasi, alat-alat pengangkutan dan alatalat berat kendaraan, inventaris dan aset tetap lainnya dapat dilihat pada Tabel 8.

Tabel 8. Nilai Penyusutan Pabrik Teh PT. Perkebunan Nusantara VI Unit Usaha Kayu Aro Tahun 2019

\begin{tabular}{clr}
\hline No & \multicolumn{1}{c}{ JenisAktiva } & Penyusutan $($ Rp/tahun) \\
\hline 1. & Bangunan & 189.991 .862 \\
2. & MesindanInstalasi & 4.388 .338 .068 \\
3. & Alat-alatPengangkutan, & 26.510 .528 \\
& AlatBeratKendaraan & 238.937 .756 \\
4. & InventarisdanAsetTetapLainnya & \\
\hline & Total BiayaPenyusutan & 4.843 .778 .214 \\
\hline
\end{tabular}

Sumber : PT. Perkebunan Nusantara VI Unit Usaha Kayu Aro, 2019.

Pada Tabel 8 terlihat biaya penyusutan pabrik teh PT. Perkebunan Nusantara VI Unit Usaha Kayu Aro tahun 2019 adalah sebesar Rp.4.843.778.214.
Setelah didapatkan nilai penyusutannya maka biaya tetap pada pabrik teh PT. Perkebunan Nusantara VI Unit Usaha Kayu Aro dapat dilihat pada Tabel 9.

Tabel 9. Biaya Tetap Pabrik Teh PT. Perkebunan Nusantara VI Unit Usaha Kayu Aro Tahun 2019

\begin{tabular}{clr}
\hline No & \multicolumn{1}{c}{ Jenis Biaya } & Jumlah (Rp) \\
\hline 1. & GajiKaryawanPimpinan & 1.135 .413 .352 \\
2. & GajiKaryawanPelaksana & 6.437 .630 .564 \\
3. & Penyusutan & 4.843 .778 .214 \\
4. & Biayaasuransi & 714.375 .780 \\
5. & Pajak & 966.853 .071 \\
6. & Beban Bank & 2.288 .251 \\
\hline & Total BiayaTetap & 14.100 .339 .232 \\
\hline
\end{tabular}

Sumber : PT. Perkebunan Nusantara VI Unit Usaha Kayu Aro, 2019.

Pada Tabel 9 terlihat bahwa jumlah biaya gaji karyawan pimpinan sebesar Rp. 566.117.316 yang terdiri dari gaji pokok, tunjangan dan biaya sosial. Sedangkan untuk karyawan pelaksana adalah sebesar Rp. 3.268.876.829 yang terdiri dari gaji pokok dan biaya sosial. Biaya penyusutan aktiva setiap tahunnya tetap dikeluarkan perusahaan sehingga penyusutan dikelompokkan dalam biaya tetap. Perusahaan juga mengeluarkan biaya asuransi, pajak dan beban bank.

\section{c. Biaya Variabel}

Biaya-biaya variabel yang dikeluarkan pabrik teh PT. Perkebunan
Nusantara VI Unit Usaha Kayu Aro tahun 2019 dapat dilihat pada Tabel 10. Dari Tabel 10 dibawah terlihat bahwa total biaya tenaga kerja langsung adalah sebesar Rp.2.045.217.960. Biaya yang tergolong sebagai biaya overhead pabrik adalah biaya bahan bakar non BBM (Cangkang), biaya pemeliharaan bangunan pabrik, biaya pemeliharaan mesin dan peralatan, biaya alat dan perlengkapan, biaya pengepakan, biaya listrik dan biaya air. Biaya yang tergolong sebagai biaya administrasi adalah biaya alat tulis yaitu untuk pembelian kwitansi, tinta, kertas yang meningkat seiring dengan bertambahnya volume produksi dan biaya komputer. 
Tabel 10. Biaya Variabel Pabrik Teh PT. Perkebunan Nusantara VI Unit Usaha Kayu Aro Tahun 2019

\begin{tabular}{clr}
\hline No & \multicolumn{1}{c}{ Jenis Biaya } & Jumlah (Rp) \\
\hline 1. & Biaya Bahan Baku & 51.506 .725 .550 \\
2. & Biaya Tenaga Kerja Langsung & 2.045 .217 .960 \\
3. & Biaya Extra Fooding & 10.392 .897 \\
4. & Biaya Pengolahan Mutu Limbah & 38.580 .120 \\
5. & Biaya Lingkungan & 64.368 .716 \\
6. & Biaya Konsumsi & 7.615 .863 \\
7. & Biaya Keamanan & 836.072 .182 \\
8. & Biaya Pemeliharaan Bangunan Rumah & 28.657 .755 \\
9. & Biaya Pemeliharaan Bangunan Perusahaan & 64.587 .327 \\
10 & Iuran-iuran & 5.412 .546 \\
11. & Premi/lembur & 802.062 .898 \\
12. & Biaya Overhead Pabrik : & 3.116 .695 .205 \\
& a.Biaya Bahan Bakar Non BBM (Cangkang) & 86.611 .265 \\
& b.Biaya Pemeliharaan Bangunan Pabrik & 3.332 .723 .061 \\
& c.Biaya Pemeliharaan Mesin dan Peralatan & \\
& d. Biaya Alat dan Perlengkapan & 29.661 .948 \\
& e. Biaya Pengepakan & 2.196 .045 .537 \\
& f. Biaya Listrik & 3.018 .416 .773 \\
& g. Biaya Air & 60.793 .467 \\
Biaya Adminstrasi Kantor: & \\
a. Biaya Perlengkapan Kantor & 20.434 .578 \\
& b. Biaya Komputer & 54.209 .700 \\
\hline & Total Biaya Variabel & 67.325 .285 .347 \\
\hline
\end{tabular}

Sumber : PT. Perkebunan Nusantara VI Unit Usaha Kayu Aro, 2019

Dari Tabel 10 total biaya variabel pabrik teh PT. Perkebunan Nusantara VI Unit Usaha Kayu tahun 2019 adalah Rp. 67.325.285.347 dan biaya tetap adalah $\mathrm{Rp}$. 14.100.339.232. Dari total biaya tetap tersebut ada yang dibayar tunai sebesar Rp. 9.256.561.018 dan ada yang diperhitungkan atau biaya terbenam (sunk cost) yaitu biaya penyusutan sebesar Rp.4.843.778.214. Sedangkan harga jual produk adalah $\mathrm{Rp}$. 17.400.

\section{d. Perhitungan Titik Impas}

Total Produksi $=3.285 .636 \mathrm{~kg}$

Total Penjualan $=4.685 .570 \mathrm{~kg}$

Biaya Tetap = Rp. 14.100.339.232

Biaya Variabel $=$ Rp. 67.325.285.347

Biaya Variabel per kg $=\frac{\text { Biaya Variabel }(\mathrm{Rp})}{\text { Total Produksi }(\mathrm{kg})}$

$$
\begin{aligned}
& =\frac{R p \cdot 67.325 .285 .347}{4.685 .570 \mathrm{~kg}} \\
& =\mathrm{Rp} \cdot 20.491
\end{aligned}
$$

Harga Jual Produk per kg

$$
\begin{aligned}
& =\frac{\text { Pendapatan }(\mathrm{Rp})}{\text { Volume Penjualan }(\mathrm{kg})} \\
& =\frac{\text { Rp.81.529.553.052 }}{4.685 .570 \mathrm{~kg}} \\
& =\mathrm{Rp} .17 .400
\end{aligned}
$$

Margin Kontribusi per kg

= Biaya Variabel per $\mathrm{kg}$ - Harga Jual Per Kg

$=\quad$ Rp. $20.491-$ Rp. 17.400 
$=$ Rp. 3.091

Titik Impas Produk (Kg)

$=\frac{\text { Biaya Tetap }(R p)}{\text { Margin Kontribusi per } \mathrm{kg}(\mathrm{Rp})}$

$=\frac{\operatorname{Rp} \cdot 14.100 \cdot 339.232}{\operatorname{Rp} .3 .091}$

$=4.562 .047 \mathrm{~kg}$

Titik Impas Produk (Rp)

$=$ Titik Impas Produk (kg) x Harga Jual Per kg

$=4.562 .047 \mathrm{~kg}$ x Rp. 17.400

$=$ Rp. 79.379.611.052
Berdasarkan komponen biaya diatas maka didapatkan nilai titik impas pabrik teh PT. Perkebunan Nusantara VI Unit Usaha Kayu Aro tahun 2019 yaitu pada tingkat penjualan sebesar $4.562 .047 \mathrm{~kg}$ atau pada tingkat penjualan senilai $\mathrm{Rp}$. 79.379.611.052. Artinya pada saat jumlah produksi dan penjualan tersebut perusahaan tidak memperoleh laba dan juga tidak mengalami kerugian. Pendekatan titik impas ini selain dilakukan dengan pendekatan matematis juga dapat dilakukan dengan pendekatan grafik seperti yang terlihat pada Gambar 2 dibawah ini.

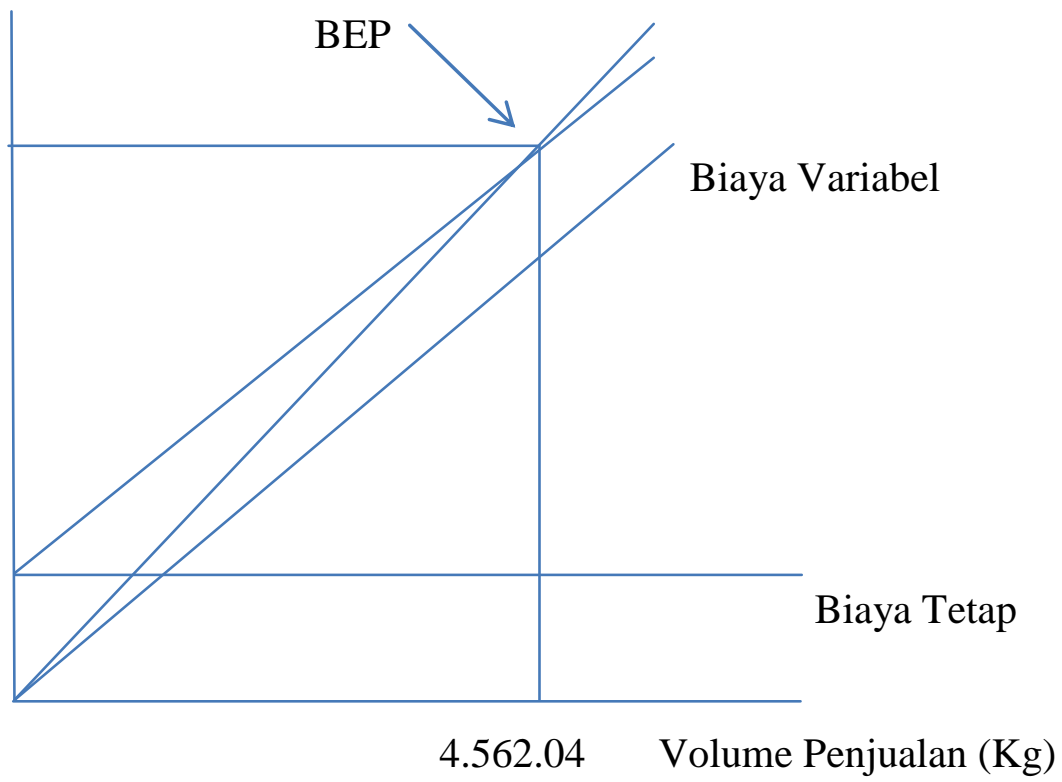

Gambar 2. Grafik Titik Impas Pabrik Teh PT. Perkebunan Nusantara VI Unit Usaha Kayu Aro, 2019

Pada Gambar 2 terlihat bahwa titik impas terjadi pada saat tingkat penjualan sebesar $4.562 .047 \mathrm{~kg}$ atau senilai Rp. 79.379.611.052. Maka apabila penjualan perusahaan diatas titik impas maka perusahaan akan mendapatkan laba dan apabila penjualan perusahaan dibawah titik impas akan menderita kerugian.

Apabila nilai titik impas ini dihubungkan dengan volume penjualan pada tahun 2019, maka dapat terlihat bahwa volume penjualan pada tahun 2019 nilainya lebih tinggi yaitu sebesar $3 \%$ jika dibandingkan dengan penjualan pada tingkat titik impas. Jika dibandingkan dengan realisasi volume penjualan tahun 2019 sebesar $4.685 .570 \mathrm{~kg}$, terlihat bahwa yang dicapai telah memberikan keuntungan pada perusahaan. Selanjutnya jika dilihat dari nilai penjualan, impas diperoleh pada tingkat penjualan sebesar Rp. 79.379.611.052. Dibandingkan dengan realisasi nilai penjualan tahun 2019 sebesar Rp. 81.529.553.052 juga menunjukkan bahwa nilai penjualan yang dicapai perusahaan telah memberikan keuntungan kepada perusahaan. 


\section{Kesimpulan}

Dari hasil penelitian dapat ditarik kesimpulan sebagai berikut :

1. Aktivitas produksi yang berlangsung pada pabrik teh PT. Perkebunan Nusantara VI Unit Usaha Kayu Aro dilakukan secara terus menerus (Continue Process). Permasalahan yang terjadi adalah umur pabrik yang cukup lama dan terjadinya penurunan pasokan bahan baku.

2. Nilai Titik Impas pada pabrik teh PT. Perkebunan Nusantara VI Unit Usaha Kayu Aro tahun 2019 adalah pada tingkat penjualan sebesar $4.562 .047 \mathrm{~kg}$ atau pada tingkat penjualan sebesar Rp. 79.379.611.052.

\section{Daftar Pustaka}

Ananda, G dan Hamidi. (2019). Analisis Break Even Point Sebagai Alat Perencanaan Laba Pada Perusahaan Manufaktur Sub Sektor Makanan Dan Minuman Yang Terdaftar Pada Bursa Efek Indonesia Tahun 20142017.Measurement : Jurnal Akuntansi, 13(1), 1-10.

Badan Pusat Statistik Provinsi Jambi. (2019). Provinsi Jambi Dalam Angka 2019. Jambi : Badan Pusat Statistik Provinsi Jambi.

BPS. (2017). Statistik Teh Indonesia. http://bps.go.id.

Choiriyah, V. U., Dzulkirom, $\mathrm{M}$ dan Hidayat, R.A. (2016). Analisis Break Even Point Sebagai Alat Perencanaan Penjualan Pada Tingkat Laba Yang Diharapkan (Studi Kasus Pada Perhutani Plywood Industri Kediri Tahun 2013-2014). Jurnal Administrasi Bisnis (JAB), 35(1), 196206.

Hindersah, R., Adityo, B., dan Suryatmana, P.(2016). Populasi Bakteri Dan Jamur Serta Pertumbuhan Tanaman Teh (Camellia Sinensis L.)
Pada Dua Jenis Media Tanam Setelah Inokulasi Azotobacter. Agrologia, Jurnal Ilmu Budidaya Tanaman, 5(1), 1-9.

Maruta, H. (2018). Analisis Break Even Point (BEP) Sebagai Dasar Perencanaan Laba Bagi Manajemen. JAS (Jurnal Akuntansi syariah), 2(1), 9-28.

Munawir, S. (2004). Analisa Laporan Keuangan. Liberty. Jakarta.

Nazir, Moh. (2013). Metode Penelitian. Ghalia Indonesia. Bogor.

Purwanti, A dan Darsono, P. (2013). Akuntansi Manajemen Edisi 3 Revisi. Mitra Wacana Media. Jakarta.

Rudzali, A dan Damayanti, S. (2015). Analisis Dan Perhitungan Break Even Point (Bep) Sales Mix Paving Blok Di Pt Borneo Abadi Samarinda. Account Jurnal Akuntansi, Keuangan Dan Perbankan, 1(4), 266-275.

Siswanto, H. (2018). Analisis Break Event Point Terhadap Perencanaan Laba CV. UUL Anugerah Surabaya . Jurnal Akuntansi Dan Teknologi Informasi (JATI), 12(1).

Sumarno, W., \& Fikriman, F. (2019). Eksistensi Perkebunan Tebu Rakyat sebagai Sumber Pendapatan Petani. JAS (Jurnal Agri Sains), 3(2).

Supriadi, A., Nurulita, S., Dan Yefni. (2018). Analisis Break Even Point Sebagai Dasar Perencanaan Laba Pada Gedung Serba Guna Politeknik Caltex Riau. Jurnal Akuntansi Keuangan dan Bisnis, 11(1), 31-41.

Thanoza, H, Silsia, D., dan Efendi, Z. (2016). Pengaruh Kualitas Pucuk Dan Persentase Layu Terhadap Sifat Fisik Dan Organoleptik Teh Ctc (Crushing Tearing Curling). Jurnal Agroindustri, 6(1), 42-50 